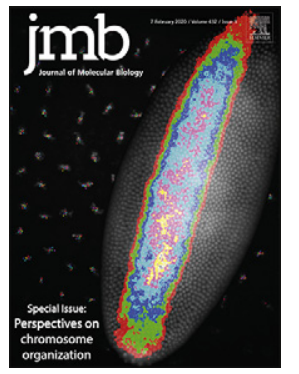

\title{
The Secret Life of Chromosome Loops upon DNA Double-Strand Break
}

\section{Coline Arnould and Gaëlle Legube}

LBCMCP, Centre de Biologie Integrative (CBI), CNRS, Université de Toulouse, UT3, Toulouse, France

Correspondence to Gaëlle Legube: gaelle.legube@univ-tlse3.fr

https://doi.org/10.1016/j.jmb.2019.07.036

\begin{abstract}
DNA double-strand breaks (DSBs) are harmful lesions that severely challenge genomic integrity, and recent evidence suggests that DSBs occur more frequently on the genome than previously thought. These lesions activate a complex and multilayered response called the DNA damage response, which allows to coordinate their repair with the cell cycle progression. While the mechanistic details of repair processes have been narrowed, thanks to several decades of intense studies, our knowledge of the impact of DSB on chromatin composition and chromosome architecture is still very sparse. However, the recent development of various tools to induce DSB at annotated loci, compatible with next-generation sequencing-based approaches, is opening a new framework to tackle these questions. Here we discuss the influence of initial and DSB-induced chromatin conformation and the strong potential of 3C-based technologies to decipher the contribution of chromosome architecture during DSB repair.
\end{abstract}

(C) 2019 The Authors. Published by Elsevier Ltd. This is an open access article under the CC BY-NC-ND license (http://creativecommons.org/licenses/by-nc-nd/4.0/).

\section{The DNA Double-Strand Break Response and Repair}

DNA double-strand breaks (DSBs) represent challenging lesions for cells, as they can lead to major genome rearrangement such as translocations, aneuploidy, and deletions/amplifications. While previously considered to be almost exclusively induced by environmental agents (radiation, chemicals) with the exception of programmed induction by endogenous nucleases (during meiosis and immunoglobulin loci rearrangement), it is now well admitted that DSBs are also regularly triggered during normal cell metabolism. More specifically, the development of DSB mapping technologies, such as BLESS, BLISS, DSBCapture, END-seq or BrITL [1-6] (reviewed in Ref. [7]), has recently revealed insights on the distribution of endogenous DSBs across the genome. These genome-wide analyzes identified transcriptionally active loci and transcription start sites (TSS) as particularly prone to breakage (e.g., Refs. [3,6], reviewed in Refs. [7,8]). These studies also further revealed a compelling connection between DSB production and chromosome architecture, identifying binding sites for CTCF and cohesin (main genome organizers) as preferential damage sites due to topoisomerase activity and/ or fork collapse [5,9-12]. At loop anchors, topoisomerase II recruitment could further trigger production of DSB upon transcriptional activation of close-by genes [9-11].

Beyond the influence of chromosome loops in DSB formation, supported by a growing body of evidence, an emerging concept is also that DSB formation further modifies chromosome architecture and organization in the nuclear space. Given the potential for unscheduled rejoining of two DSBs to trigger translocations, and the previously reported bias for translocation to occur in active loci in cancer cells, it is urgent to understand how DSBs modify chromosome organization and architecture and how this impacts genome (in)stability. 
(a)
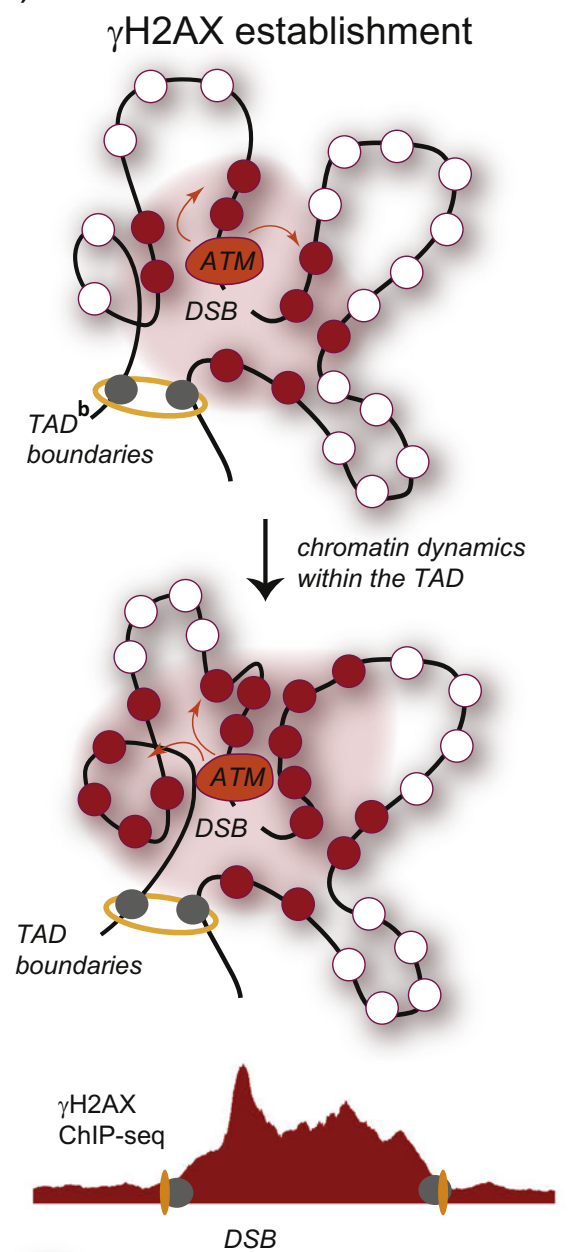

unphosphorylated nucleosome $\gamma \mathrm{H} 2 \mathrm{AX}$ nucleosome (b)

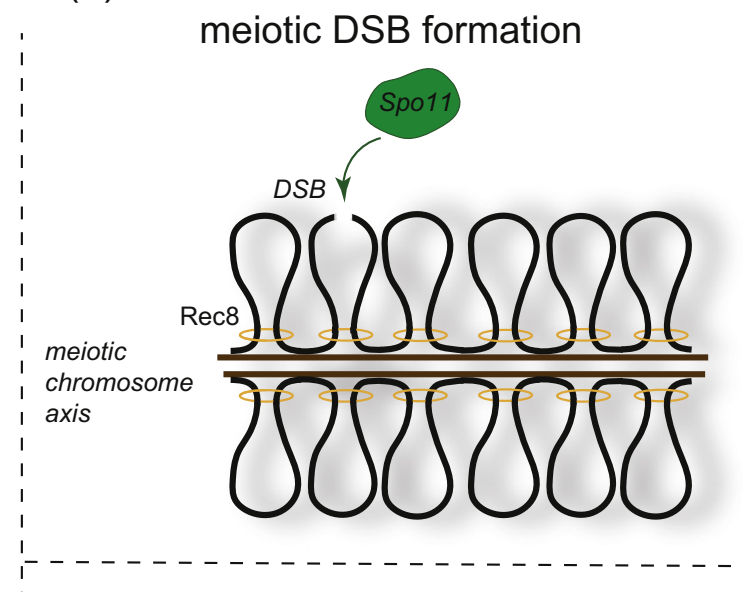

(c)
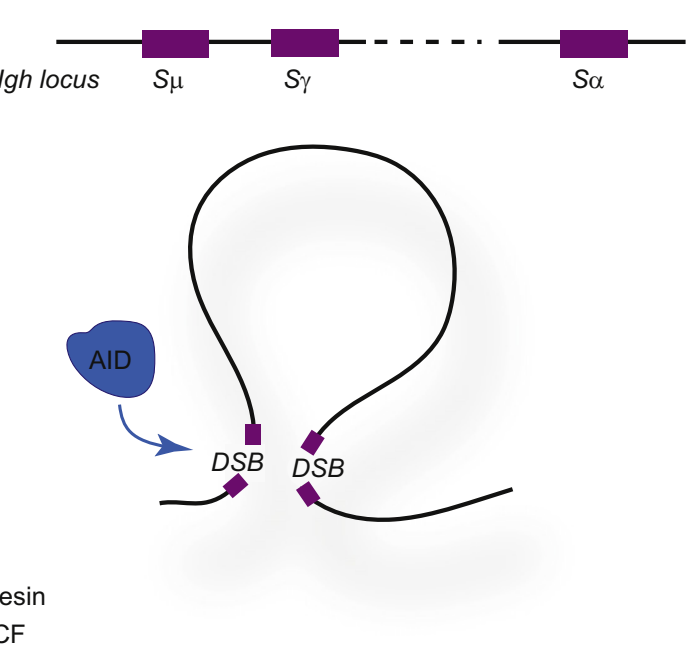

Fig. 1. Contribution of the initial chromatin conformation into $\mathrm{yH} 2 \mathrm{AX}$ establishment and programmed DSB induction and repair. (A) The initial chromosome conformation may dictate $\mathrm{yH} 2 \mathrm{AX}$ spreading following DSB induction. In this model, ATM, the main H2AX kinase is locally recruited at the DSB. Once bound, it is able to phosphorylate H2AX containing nucleosomes brought to its physical proximity, thanks to chromatin dynamics that takes place within the TAD. Sustained signaling and ATM activation eventually trigger the phosphorylation of $\mathrm{H} 2 \mathrm{AX}$ on the entire TAD. In this model, $\mathrm{YH} 2 \mathrm{AX}$ distribution, as observed by ChIP-seq, should mimic the $3 \mathrm{D}$ chromatin conformation. (B) Chromosome conformation is critical during meiotic breaks formation by Spo11. During prophase, meiotic chromosomes are strongly reorganized with the formation of DNA loops anchored to a proteinaceous axis. Spo11 generates DSBs within DNA loops, which can further pair with the homologous chromosome in order to produce crossover and to complete meiosis. The 3D chromatin structure and the chromosomal axis are required for both DSB production by Spo11 and to ensure the "homologous bias" (i.e., the choice of the homologous chromosome rather than the sister chromatid, as a template for HR). (C) Chromosome conformation is also critical for the rearrangements that occur on immunoglobulin loci, in order to generate immunoglobulin isotypes (class switch recombination (CSR)) and the antibody repertoire (VDJ recombination). For example, during CSR (shown here), the long-range physical interactions between switch (S) sequences on the heavy chain locus (Igh) allow two DSBs to be rejoined.

Various pathways contribute to repair DSB in eukaryotes, including homologous recombination (HR) and non-homologous end joining (NHEJ) (reviewed in Refs. [13,14]). HR entails processing of DNA ends in order to generate single strand DNA (resection) which will invade a homologous copy of the broken locus, further used as template for DNA synthesis. NHEJ rather directly rejoins the two DNA ends. Mechanistically, these two pathways are profoundly different and likely necessitate different 
chromatin composition and properties for proper execution. At a molecular level, ChIP-seq and imaging studies have started to determine the histone modifications landscape assembled at DSB, as well as their function in DSB repair (reviewed in Ref. [15]). However, the conformation of chromatin around DSBs and the chromosome organization in damaged nuclei have only recently started to be investigated.

One of the striking feature of the DNA damage response is the assembly of microscopically visible foci in the nucleus, which display massive phosphorylation of the $\mathrm{H} 2 \mathrm{AX}$ histone variant $(\mathrm{yH} 2 \mathrm{AX}$ ) [16], as well as accumulation of repair factors. Although efforts have been made to understand the protein content of these foci, their exact composition and conformation at the DNA level is still unknown. One of the main reasons for this scarcity of data stands in the long-lasted inability to control the position of induced DSB on the genome. Indeed, except in yeast where the ability of the $\mathrm{HO}$ endonuclease to cleave the MAT locus for mating type switching was utilized as a tool to investigate site-specific DSB repair, DSBs have routinely been induced by exposure to genotoxic (drugs and radiation) generating damage in a heterogeneous manner in the cell population and at unknown (but not necessarily random) positions, which precluded the use of Chromosome Conformation Capture (3C)based methods to investigate chromatin conformation around DSBs. This has been solved recently, thanks to the development of several tools to induce breaks at annotated positions, using restriction enzymes and homing endonucleases (e.g., AsiSI, I-Ppol), Zinc Fingers and TALE Nucleases, or the CRISPR/Cas9 system [17]. With these novel experimental systems, the molecular characterization of DNA conformation around DSB and more generally the folding of damaged chromosomes within the nucleus are now within reach.

Two main questions should primarily focus our attention. First, we need to understand how the initial chromosome conformation and organization in the nucleus may contribute to ensure proper DSB signaling and repair. Second, we shall wonder how this initial chromatin conformation is modified upon damage to participate in repair events safeguarding genome integrity.

\section{How Does Initial Chromatin Architecture Contribute to DSB Signaling and Re- pair?}

The genomic localization of DSBs strongly impacts their signalization and repair. For instance, clear evidence suggests that DSB occurring in heterochromatin [18,19], rDNA [20] or transcribed loci [8] displays specialized repair pathways. The chromatin composition of the broken locus (involving for example histone marks like H3K36me3 for transcription-coupled DSB repair [21-23], or bona fide chromatin constituents such as KAP1 for heterochromatic repair $[24,25])$ and its spatial position within the nucleus (e.g., at the nuclear periphery [26]) have been clearly established as main contributors in determining which pathway should be used at each genomic location (a decision known as "DSB repair pathway choice") [27]. However, at this stage it is not known whether, beyond the sub-nuclear localization of a locus and its chromatin composition, the chromosome conformation also plays a role in DSBs signaling and repair. Nevertheless, some hints suggest that this is likely the case.

\section{Initial chromatin conformation regulates HR}

The fact that chromosome conformation within the nucleus regulates $\mathrm{HR}$ is particularly evident from studies in yeast, showing that efficiency of sub-telomeric recombination is strongly affected by telomeres clustering and anchorage [28,29]. Beyond telomeres, moving an $\mathrm{HO}$ site at different positions along yeast chromosomes revealed a compelling correlation between the frequency of HR and the proximity with the homologous locus, observed by $3 \mathrm{C}$ before damage induction [30]. Thus, initial spatial proximity between the broken locus and a donor sequence is a key feature that determines the efficiency of HR.

\section{Initial chromatin conformation could regulate YH2AX spreading}

Evidence also suggests that chromosome architecture might control $\mathrm{YH} 2 \mathrm{AX}$ spreading (reviewed in Refs. [31,32]) (Fig. 1). Indeed, yH2AX mapping by ChIP-chip around multiple DSBs induced by the restriction enzyme AsiSI in human cells (the socalled DIvA cell line for DSB Induced via AsiSI) revealed that $\mathrm{\gamma H} 2 \mathrm{AX}$ spreads on 1-2 megabases surrounding DSBs, in a manner that is (i) reproducible and constrained within boundaries, (ii) not necessary symmetrical around the break and (iii) uneven with peaks and valleys, suggesting that the surrounding epigenomic landscape and/or chromatin architecture may regulate $\mathrm{yH} 2 \mathrm{AX}$ spreading [33]. A follow-up study uncovered a potential function for cohesins in regulating $\mathrm{yH} 2 \mathrm{AX}$ distribution and in insulating transcribed genes encompassed in YH2AX domains from transcription extinction [34]. Moreover, by then, comparison of published $\mathrm{Hi}-\mathrm{C}$ data generated in undamaged cells [35] with $\mathrm{yH} 2 \mathrm{AX}$ domains boundaries revealed a striking tendency of $\mathrm{yH} 2 \mathrm{AX}$ spreading to stop at topologically associating domain (TAD) boundaries [34]. In agreement, the occupancy of the chromatin looping factor CTCF was found juxtaposed to $\mathrm{YH} 2 \mathrm{AX}$ foci using superresolution light microscopy [36]. Altogether, these 


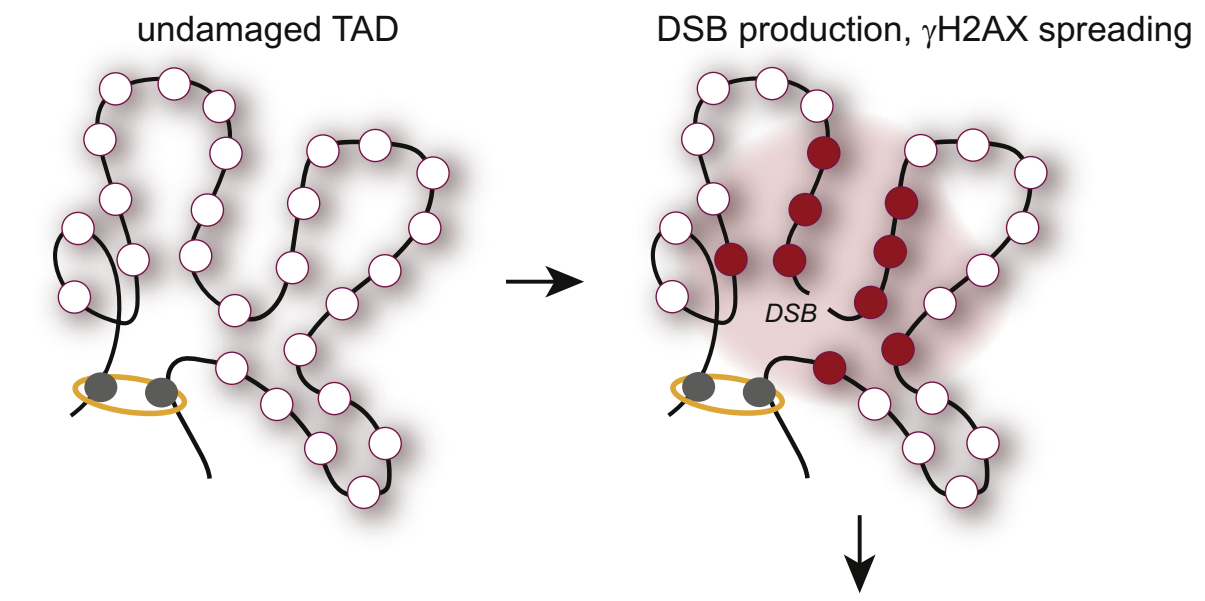

- enhanced cis interaction

- enhanced mobility

due to

nucleosome loss?

resection?

histone modifications?

changes in DNA loops?
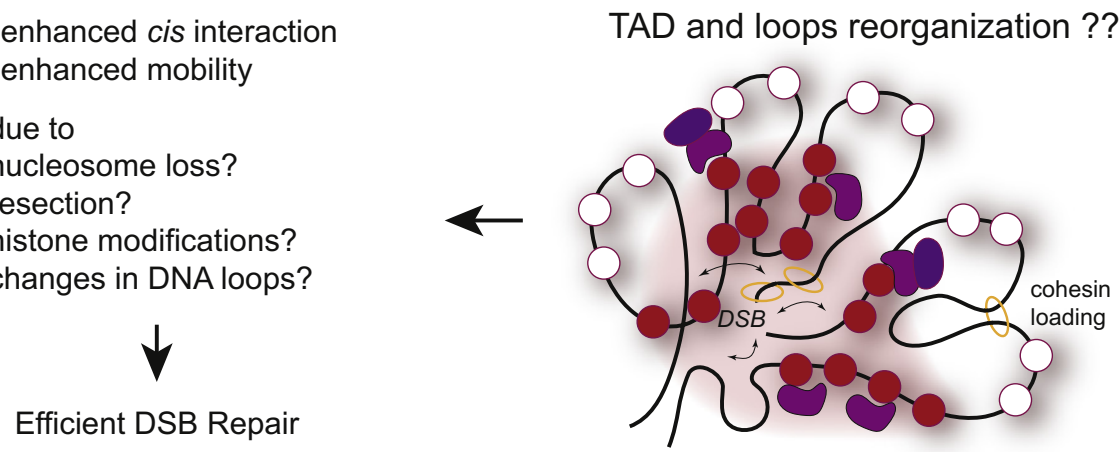

unphosphorylated nucleosome

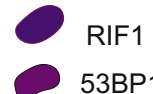

RIF1

$\gamma \mathrm{H} 2 \mathrm{AX}$ nucleosome

53BP1 $\longrightarrow$ cohesin

Fig. 2. DSB-induced modification(s) of the chromosome conformation in cis to the break. Following DSB production and YH2AX spreading, the 3D conformation of damaged TAD could also be modified, due to the binding of cohesin, CTCF or repair proteins with potential function in chromatin architecture such as 53BP1 and RIF1. The DSB-induced histones modifications (including $\mathrm{YH} 2 \mathrm{AX}$ spreading), nucleosome loss or/and generation of single strand DNA (resection) may also collectively change the dynamics of chromatin within TADs. Altogether, these changes could translate in enhanced mobility and efficient DSB repair.

results raise the exciting hypothesis that once bound to the DSB, the kinase(s) involved in H2AX phosphorylation allows $\mathrm{YH} 2 \mathrm{AX}$ spreading by modifying nucleosomes brought into spatial proximity, thanks to the initial chromatin architecture surrounding the DSB (the "Intra-TAD model" [31,32]) rather than by linearly walking along the chromosome. This hypothesis is further supported in yeast, where $\mathrm{yH} 2 \mathrm{~A}$ spreading was also found to occur in trans (on other chromosomes) when a DSB was induced close to a centromere, as a consequence of centromeres clustering within nuclei [37].

\section{Initial chromatin conformation regulates production and repair of programmed DSB}

Beyond these evidences that pre-existing chromosome architecture contributes to DSB signaling and repair, chromosome organization is also likely a key feature in the repair of programmed DSBs induced during meiosis and immunoglobulin loci rearrangements (Fig. 1). During the prophase of meiosis, chromosomes undergo profound reorganization which entails progressive condensation, loss of long-range inter-chromosomal contacts, TADs dissolution and the formation of arrays of chromatin loops anchored to a chromosomal axis [38-43]. Within this context, the topoisomerase-like Spo11 endonuclease induces DSBs in a tightly regulated manner, which are further processed and-for some of them-converted into mature crossovers, necessary to ensure chromosome segregation and completion of meiosis. Importantly, crossover formation depends on the "homologous bias" that consists in choosing the homologous chromosome as a template over the sister chromatid (reviewed in Refs. $[44,45])$. Notably, germ cells-specific chromosome architecture plays a critical role in both determining 
the distribution of DSBs along the chromosome and in the homologous bias. Indeed, in Saccharomyces cerevisiae, Spo11-dependent DSBs are being formed within DNA loops in a manner that depends on multiple axial factors such as the meiosis-specific cohesin subunit Rec8 [46,47], the Spp1 protein [48], Red1 [46], or the Spo11 accessory complex, RRM (Rec114-Mei4-Mer2) [49]. In addition, components of the structural axis (such as Rec8 or Red1) are also strongly involved in regulating the homologous bias [47] and the axis further acts as a platform for recombination. This peculiar chromosome architecture that is assembled in meiotic cells hence displays a prominent role into DSB production and repair.

Programmed DSBs also occur at the Immunoglobulin (Ig) loci to ensure $V(D) J$ recombination for antibody diversification and class switch recombination (CSR) to generate different antibody isotypes. On the Ig heavy-chain locus (Igh), productive CSR results in a deletion event after recombination between two Switch $\left(\mathrm{S}_{\mathrm{H}}\right)$ sequences, located up to $100 \mathrm{~kb}$ apart. Here as well, the initial 3D chromatin conformation exerts a regulatory role on both break formation and repair [50,51] (reviewed in Ref. [52]). For instance, deletion of the CTCF-binding sites encompassed in the Igh Superanchor (SA), correlates with a decrease in cohesin-mediated loop extrusion (detected by "stripes" on Hi-C maps) and reduces CSR [50]. Similarly, V(D)J recombination, both on Igk and Igh loci, strongly relies on long-range chromatin interactions. For instance, deletion of CTCF-binding sites in the intergenic control region-1 (IGCR1) upstream the $D$ segments on Igh locus impairs normal $V$ to DJ recombination and B-cell development in a manner that coincides with modification of chromosomal loops $[53,54]$. Similarly, deletion of a specific enhancerCTCF-bound element on the Igk locus perturbs the antibody repertoire in a manner that also correlates with the loss of long-range interaction [55].

It is hence clear from all these studies that the initial chromosome architecture contributes to DSB signaling, processing and repair. However, while our knowledge regarding the role of long-range chromatin interactions and TADs during repair of programmed DSBs quickly expands, our understanding of their function into repair of endogenous DSBs in somatic cells still lags behind and will necessitate future 3C-based studies using sequence-specific DSB induction systems.

\section{How Does Chromatin Architecture Change Post-damage In Cis to DSB, within yH2AX Domains?}

Another important question that needs to be addressed is the nature of the changes in chromosome architecture following damage (Fig. 2). Indeed, DSB-induced modifications in the size of DNA loops or the position of TADs boundaries could regulate chromatin flexibility (stiffness), thereby regulating the DSB mobility in the nucleus [56]. This could also help to "burry" (i.e., protect) the DSB from its environment, which therefore may have profound impacts on translocation biogenesis, partner choice for HR and more generally on genome integrity. Plenty of evidence supports that chromatin in cis to DSB displays a different behavior in terms of mobility, rigidity and compaction (reviewed in Refs. [31,57]). In particular, laser-mediated, localized damage triggers a rapid chromatin decompaction at the sites of breaks [58-60], in agreement with observations that $\mathrm{yH} 2 \mathrm{AX}$ foci displays decondensed-like appearance $[61,62]$, suggesting that indeed a DSB induces dramatic changes in chromatin conformation in cis. However, nearly all studies were performed using imaging, and our current knowledge of DSB-promoted 3D changes at the level of DNA sequence remains incredibly sparse. The first experiment using $3 \mathrm{C}$ methodology to assess cis modification of long-range interactions was performed in yeast following induction of a single DSB within the MAT locus by the $\mathrm{HO}$ endonuclease [63]. Strikingly long-range contacts were dramatically reduced following DSB in asynchronous cells, while such a decrease was not observed in G1arrested cells [63], suggesting that end-processing (which occurs specifically in S/G2) rather than $\mathrm{yH} 2 \mathrm{~A}$ spreading and checkpoint activation (occurring all throughout the cell cycle) was responsible for decreased chromosomal contacts. Reduced chromosome interaction frequency was further shown to depend on Rad51 loading and attributed to the sequestration of the DSB at the nuclear periphery $[63,64]$ (see next section). However, this decrease in long-range interaction following DSB was not reported in human cells [65]. Instead, by using Capture Hi$\mathrm{C}$ in the DlvA system (in which 100 DSBs can be induced at annotated loci $[21,33])$, it was shown that, in average, the DSB itself engages more long-range contacts with neighboring sequences encompassed in $\mathrm{yH} 2 \mathrm{AX}$ domains than before break induction [65] (reviewed in Ref. [66]). Contrary to yeast, DSBs have not been found to relocate to the nuclear envelope in mammalian cells, which may account for the discrepancy between both studies. Notably, enhanced interactions between the DSB and DNA loci embedded in $\mathrm{yH} 2 \mathrm{AX}$ domains would be in agreement with the increased mobility of DNA ends reported in multiple studies (reviewed in Refs. $[31,57,67])$.

Of note, the resolution achieved by Capture-HiC in the above-mentioned study [65] was insufficient to draw conclusions regarding the DNA loops reorganization around DSBs. Interestingly, although this was not directly assessed using $\mathrm{Hi}-\mathrm{C}$ or $4 \mathrm{C}$ experiment, strong evidence suggests that chromosome loops are reorganized in cis to DSB induced by 
(a)

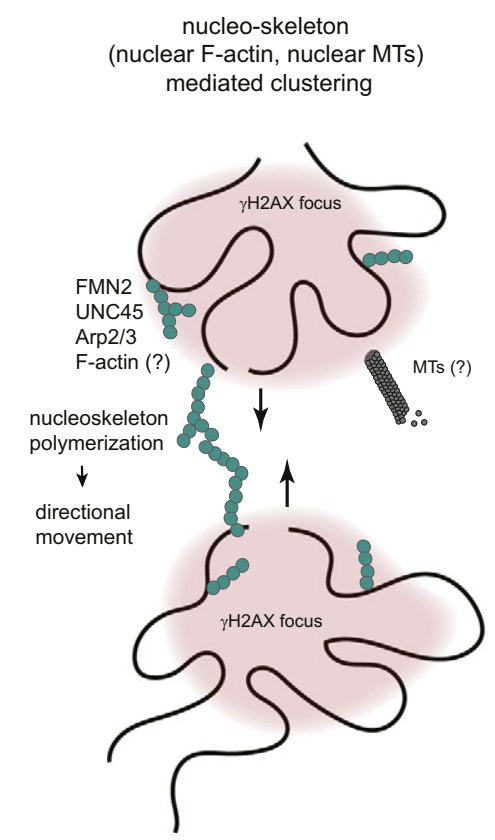

(b)

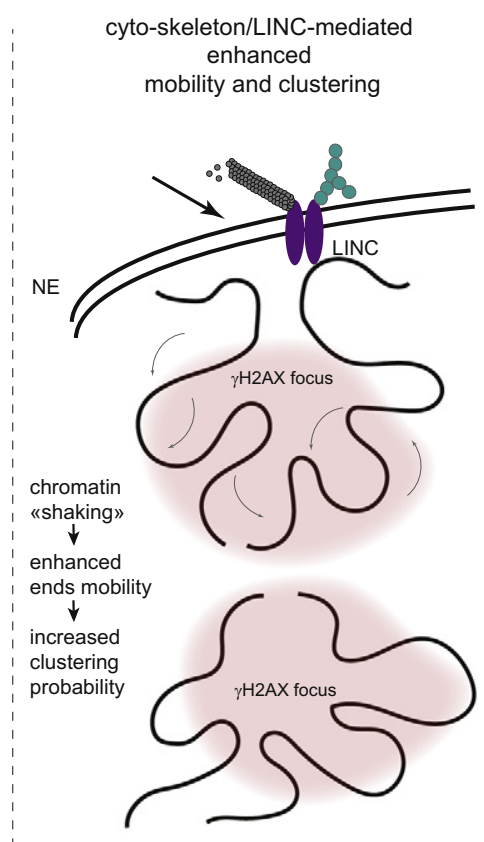

(c)

phase separation-mediated clustering

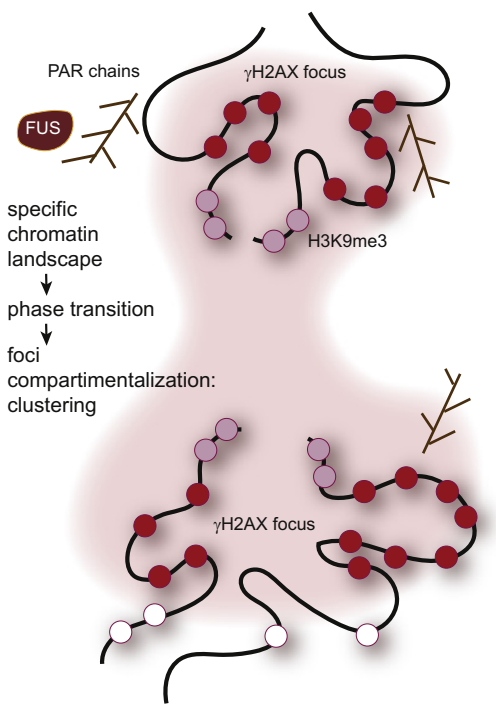

Fig. 3. Changes in chromosome conformation upon damage in trans such as during DSB clustering. Both live cell imaging and $3 \mathrm{C}$-based methods allowed to demonstrate that multiple DSBs can coalesce together within a single $\mathrm{YH} 2 \mathrm{AX}$ focus. However, the mechanisms that ensure clustering are unclear and may entail various pathways. (A) The nucleoskeleton (both polymerized actin and/or microtubules) could allow for DSB mobilization and clustering in a directional manner. (B) The cytoskeleton could also contribute to clustering thanks to the transmission of forces from cytoskeleton to chromatin via the LINC complex, embedded in the nuclear envelope. In this context, the forces transmitted to chromatin may trigger a general increase in chromatin dynamics, increasing the probability of $\mathrm{yH} 2 \mathrm{AX}$ collision/ clustering. (C) Finally, the chromatin landscape established following damage could allow for compartmentalization, thanks to phase separation.

Spo11 in yeast meiotic cells. Indeed, in a WT strain, DSB production by Spo11 is negatively counteracted in a 100-kb window around an initial Spo11created break. Notably, this phenomenon, called negative interference, depends on the yeast ATM ortholog Tel1, one of the main kinases activated during the DNA damage response [68]. This led to the proposal that, in cis to an initial break, ATM/Tel1 activation could drive chromatin loops reorganization, themselves being required and targeted for DSB formation (see previous section), hence contributing to negative interference and ensuring a proper distribution of DSBs along meiotic chromosomes $[68,69]$.

It is likely that the usual suspects shaping chromosome architecture, that is, the cohesin complex and CTCF, are involved in such DSBinduced DNA loops reorganization. Studies in both yeast and mammals have demonstrated that cohesins and their loaders/regulators are recruited at DSBs [34,70-81], and post-translationally modified following damage (e.g., Refs. [76,77,82-85]). Strikingly, in yeast, DSB-induced cohesin binding takes place on a large chromosomal domain surrounding the break $[71,72]$, in contrast to mammalian cells, where it only occurs on few kilobases [34]. While cohesin loading has long been involved in sister chromatid cohesion during HR $[75,83,84,86-90]$, in mammalian cells, it is also recruited at DSBs during G1 phase $[34,74]$, suggesting that this complex exerts a function beyond sister chromatid cohesion at DSB. In agreement, cohesin regulates transcriptional repression of genes immediately in cis to DSBs [74], insulates the active genes located farther within the $\mathrm{yH} 2 \mathrm{AX}$ domain to maintain their transcription [34] and controls the NHEJ repair pathway [91]. Similarly, CTCF has also been shown to be recruited at DSBs [92-94] and to contribute to HR $[92,93]$.

Beyond these well-known architectural proteins involved in chromatin looping, DSB repair factors may also contribute to shape chromatin 3D structure in cis to DSB. Among these, 53BP1 is an interesting candidate since it was shown to spread on entire $\mathrm{yH} 2 \mathrm{AX}$ domains [95] and to be a critical determinant of the architecture of the Igh locus, even before damage formation $[51,96]$. In addition, the 53BP1 effector Rif1, which is recruited at DSB to regulate resection [97-99], is also of interest, as it was 
recently shown by $4 \mathrm{C}$-seq to be a main organizer of chromatin architecture in unchallenged cells [100]. Importantly, both factors are essential for productive CSR $[97,98,101,102]$, which further highlight their potential role in organizing the 3D structure of DSBsurrounding chromatin.

However, despite all these studies, a clear picture of the DNA conformation within $\mathrm{yH} 2 \mathrm{AX}$ foci is still awaited. Mapping of architectural proteins using ChIP-seq as well as determining chromatin conformation by 3C-based approaches around annotated DSBs will certainly help to better understand the nature and function of DSB-induced chromosome loops changes.

\section{How Does Chromatin Architecture Change Post-damage In Trans to DSB, within the Nucleus?}

In addition to the changes in cis described in the previous section, damaged chromosomes also experience more global reorganization within the nucleus. This is particularly apparent in yeast and Drosophila, where persistent, heterochromatic and/ or rDNA breaks are relocalized at the nuclear periphery [63,64,103,104] (reviewed in Ref. [31]). Similarly in mammals, DSBs induced in rDNA and $\alpha$ satellites are extruded at the periphery of the nuclear sub-compartment (nucleolus and heterochromatic focus, respectively) [105-107]. Beyond these largescale reorganizations, DSBs are also capable of clustering together (i.e., regrouping in one visible focus [65,108-115] (reviewed in Refs. [31,116]). Using Capture $\mathrm{Hi}-\mathrm{C}$ to map long-range interactions following induction of multiple annotated DSBs on the human genome, it was recently demonstrated that DSBs can cluster together if they occur in transcriptionally active, RNA Pol II-bound, loci [65] (reviewed in Refs. $[8,15,116])$. Of interest, clustering was mostly observed in G1 cells [65,108] and coincided with delayed repair [65], suggesting that it may contribute in "poising" DSB repair in order to ensure faithful genetic information recovery $[65,116]$.

The mechanism(s) at work to ensure DSB clustering and other DSB mobility events are still under investigation but may rely on both active/ directional and passive/diffusive movement (Fig. 3).

\section{Cyto and nucleo-skeleton networks}

Evidence suggests that DSB end mobility and DSB clustering are mediated at least in part, thanks to the cyto-and nucleo-skeleton network (reviewed in Refs. [116,117]). Indeed, formin 2, an actin organizer, as well as the Arp2/3 actin branching factor and the Arp2/3 activator WASP are required for clustering in human cells [65,114] (Fig. 3, left panel).
Moreover, nuclear myosin 1 and actin were recently reported as mediating damaged-induced homologous chromosome pairing in G0/G1 cells, in a manner that depends on the ability of actin to polymerize (by the use of actin mutants) [118]. Of importance, although nuclear actin filaments (Factin) have been reported and involved in relocating heterochromatic DSBs in Drosophila nuclei [119], such actin filaments still remain to be observed in mammalian nuclei. Indeed, DNA damaging agents do induce nuclear F-actin [120], but no clear link with damage sites was reported. More recently, actin was described to form foci colocalizing with $\mathrm{yH} 2 \mathrm{AX}$ rather than filaments following damage [114]. Hence, the contribution of nuclear F-actin during clustering still needs further clarification. On another hand, the microtubule (MTs) network may also contribute to DSB mobility and clustering. Perturbation of MTs using drugs impairs DNA ends mobility [121,122], although this was not observed in other settings $[115,123]$. Moreover, nuclear MTs were observed in yeast damaged nuclei and proposed to mediate directional movement [124]. While DSB-induced nuclear MTs still need to be identified in other conditions and organisms, it is nevertheless clear from many studies that the LINC complex, embedded in the nuclear envelope and connecting the cytoskeleton (including cytoplasmic MTs) to nuclear lamina and chromatin, also controls DSB mobility and clustering $[65,121]$ (reviewed in Refs. [31,116]). It was therefore proposed that the cytoskeleton may also contribute to DSB mobility and clustering by transmitting forces from the cytoplasm to chromatin through the nuclear envelope and the LINC complex [121] (reviewed in Ref. [116]) (Fig. 3, middle panel).

\section{Contribution of phase separation in compart- mentalization}

It is also tempting to speculate that phase separation could contribute into DSB clustering, as reported for heterochromatin foci formation (Fig. 3, right panel). Indeed, H3K9me3 covered chromatin tends to phase separate, thanks to the contribution of heterochromatin protein 1 (HP1) $[125,126]$. In this respect, it is of interest that HP1 is involved in DSB repair and recruited at DSB [79,127-132]. Moreover, DNA damage foci were found to form liquidlike compartments in a manner that is seeded by poly-ADP-ribose polymerase (PARP) activity and by the formation of poly-ADP-ribose (PAR) chains [133], as well as by the contribution of the lowcomplexity domain RNA binding proteins, such as FUS [134]. Notably, a recent study reported that 53BP1 foci display droplet-like behavior, and that their assembly, fusion and dissociation are phase separation dependent [135]. Hence, the chromatin landscape established in cis to DSB (including histone modifications but also low-complexity 
domain proteins, or other repair proteins recruitment at sites of damage) may contribute to compartmentalize DSB repair sites through a phase separation-driven mechanism.

\section{Concluding Remarks}

While our knowledge of the nature and function of chromatin during DSB repair recently greatly expanded, more studies are now necessary to understand the nature and function of chromatin conformation in these processes. Importantly, modifications of chromosome looping likely display essential function in safeguarding genome integrity and driving genome evolution. For instance, chromosome architecture is strongly linked to the generation of translocation involving the Igh locus [136], and DSB clustering is a key player in translocation biogenesis [137]. In conclusion, time has now come to make use of the ever growing, sequencing-based, methodologies designed to investigate chromosome architecture at the highest achievable resolution, to tackle the function of chromatin conformation and looping in genome stability.

\section{Acknowledgments}

We apologize to our colleagues whose works could not be included in this review owing to space limitations. The G.L. laboratory is funded by grants from the European Research Council (ERC-2014-CoG 647344), Agence Nationale pour la Recherche (ANR-14-CE10-0002-01 and ANR18-CE12-0015-02), the Institut National contre le Cancer (INCA), and the Ligue Nationale contre le Cancer (LNCC).

\section{Declaration of Competing Interest}

The authors have no competing interest to declare.

Received 23 May 2019;

Received in revised form 24 July 2019;

Accepted 30 July 2019

Available online 8 August 2019

Keywords:

DNA double-strand breaks repair;

DSB clustering;

YH2AX;

chromatin;

topologically associating domains
Abbreviations used:

DSB, DNA double-strand break; TSS, transcription start site; HR, homologous recombination; NHEJ, non-homologous end joining; $3 \mathrm{C}$,

Chromosome Conformation Capture; TAD, topologically associating domain; CSR, class switch recombination; MT, microtubule.

\section{References}

[1] W.X. Yan, R. Mirzazadeh, S. Garnerone, D. Scott, M.W. Schneider, T. Kallas, et al., BLISS is a versatile and quantitative method for genome-wide profiling of DNA double-strand breaks, Nat. Commun. 8 (2017) 15058, https://doi.org/10.1038/ncomms15058.

[2] A. Biernacka, Y. Zhu, M. Skrzypczak, R. Forey, B. Pardo, M. Grzelak, et al., i-BLESS is an ultra-sensitive method for detection of DNA double-strand breaks, Commun Biol 1 (2018) 181, https://doi.org/10.1038/s42003-018-0165-9.

[3] N. Crosetto, A. Mitra, M.J. Silva, M. Bienko, N. Dojer, Q. Wang, et al., Nucleotide-resolution DNA double-strand break mapping by next-generation sequencing, Nat. Methods 10 (2013) 361-365, https://doi.org/10.1038/nmeth.2408.

[4] A. Canela, S. Sridharan, N. Sciascia, A. Tubbs, P. Meltzer, B.P. Sleckman, et al., DNA breaks and end resection measured genome-wide by end sequencing, Mol. Cell 63 (2016) 898-911, https://doi.org/10.1016/j.molcel.2016.06.034.

[5] N. Shastri, Y.-C. Tsai, S. Hile, D. Jordan, B. Powell, J. Chen, et al., Genome-wide identification of structureforming repeats as principal sites of fork collapse upon ATR inhibition, Mol. Cell 72 (2018) 222-238.e11, https://doi. org/10.1016/j.molcel.2018.08.047.

[6] S.V. Lensing, G. Marsico, R. Hänsel-Hertsch, E.Y. Lam, D. Tannahill, S. Balasubramanian, DSBCapture: in situ capture and sequencing of DNA breaks, Nat. Methods 13 (2016) 855-857, https://doi.org/10.1038/nmeth.3960.

[7] N. Puget, K. Miller, G. Legube, Non-canonical DNA/RNA structures during transcription-coupled double-strand break repair: roadblocks or bona fide repair intermediates? DNA Repair (Amst) 102661 (2019)https://doi.org/10.1016/j. dnarep.2019.102661.

[8] A. Marnef, S. Cohen, G. Legube, Transcription-coupled DNA double-strand break repair: active genes need special care, J. Mol. Biol. 429 (2017) 1277-1288, https://doi.org/10. 1016/j.jmb.2017.03.024.

[9] A. Canela, Y. Maman, S.-Y.N. Huang, G. Wutz, W. Tang, G. Zagnoli-Vieira, et al., Topoisomerase II-induced chromosome breakage and translocation is determined by chromosome architecture and transcriptional activity, Mol. Cell (2019)https://doi.org/10.1016/j.molcel.2019.04.030.

[10] A. Canela, Y. Maman, S. Jung, N. Wong, E. Callen, A. Day, et al., Genome organization drives chromosome fragility, Cell 170 (2017) 507-521.e18, https://doi.org/10.1016/j.cell. 2017.06.034.

[11] H.J. Gothe, B.A.M. Bouwman, E.G. Gusmao, R. Piccinno, G. Petrosino, S. Sayols, et al., Spatial chromosome folding and active transcription drive DNA fragility and formation of oncogenic MLL translocations, Mol. Cell (2019)https://doi. org/10.1016/j.molcel.2019.05.015.

[12] R. Madabhushi, F. Gao, A.R. Pfenning, L. Pan, S. Yamakawa, J. Seo, et al., Activity-induced DNA breaks 
govern the expression of neuronal early-response genes, Cell 161 (2015) 1592-1605, https://doi.org/10.1016/j.cell. 2015.05.032.

[13] E. Mladenov, S. Magin, A. Soni, G. Iliakis, DNA doublestrand-break repair in higher eukaryotes and its role in genomic instability and cancer: cell cycle and proliferationdependent regulation, Semin. Cancer Biol. 37-38 (2016) 51-64, https://doi.org/10.1016/j.semcancer.2016.03.003.

[14] R. Scully, A. Panday, R. Elango, N.A. Willis, DNA doublestrand break repair-pathway choice in somatic mammalian cells, Nat. Rev. Mol. Cell Biol. (2019)https://doi.org/10.1038/ s41580-019-0152-0.

[15] T. Clouaire, G. Legube, A snapshot on the cis chromatin response to DNA double-strand breaks, Trends Genet. 35 (2019) 330-345, https://doi.org/10.1016/j.tig.2019.02.003.

[16] E.P. Rogakou, D.R. Pilch, A.H. Orr, V.S. Ivanova, W.M. Bonner, DNA double-stranded breaks induce histone H2AX phosphorylation on serine 139, J. Biol. Chem. 273 (1998) 5858-5868, https://doi.org/10.1074/jbc.273.10.5858.

[17] V. Mladenova, E. Mladenov, G. Iliakis, Novel biological approaches for testing the contributions of single dsbs and DSB clusters to the biological effects of high LET radiation, Front. Oncol. 6 (2016) 163, https://doi.org/10.3389/fonc.2016.00163.

[18] A. Fortuny, S.E. Polo, The response to DNA damage in heterochromatin domains, Chromosoma 127 (2018) 291-300, https://doi.org/10.1007/s00412-018-0669-6.

[19] C. Lemaître, E. Soutoglou, Double strand break (DSB) repair in heterochromatin and heterochromatin proteins in DSB repair, DNA Repair (Amst) 19 (2014) 163-168, https:// doi.org/10.1016/j.dnarep.2014.03.015.

[20] M. van Sluis, B. McStay, Nucleolar reorganization in response to rDNA damage, Curr. Opin. Cell Biol. 46 (2017) 81-86, https://doi.org/10.1016/j.ceb.2017.03.004.

[21] F. Aymard, B. Bugler, C.K. Schmidt, E. Guillou, P. Caron, S. Briois, et al., Transcriptionally active chromatin recruits homologous recombination at DNA double-strand breaks, Nat. Struct. Mol. Biol. 21 (2014) 366-374, https://doi.org/10. 1038/nsmb.2796.

[22] S.X. Pfister, S. Ahrabi, L.-P. Zalmas, S. Sarkar, F. Aymard, C.Z. Bachrati, et al., SETD2-dependent histone H3K36 trimethylation is required for homologous recombination repair and genome stability, Cell Rep. 7 (2014) 2006-2018, https://doi.org/10.1016/j.celrep.2014.05.026.

[23] M. Daugaard, A. Baude, K. Fugger, L.K. Povlsen, H. Beck, C.S. Sørensen, et al., LEDGF (p75) promotes DNA-end resection and homologous recombination, Nat. Struct. Mol. Biol. 19 (2012) 803-810, https://doi.org/10.1038/nsmb.2314.

[24] Y. Ziv, D. Bielopolski, Y. Galanty, C. Lukas, Y. Taya, D.C. Schultz, et al., Chromatin relaxation in response to DNA double-strand breaks is modulated by a novel ATM- and KAP-1 dependent pathway, Nat. Cell Biol. 8 (2006) 870-876, https://doi.org/10.1038/ncb1446.

[25] A.A. Goodarzi, T. Kurka, P.A. Jeggo, KAP-1 phosphorylation regulates CHD3 nucleosome remodeling during the DNA double-strand break response, Nat. Struct. Mol. Biol. 18 (2011) 831-839, https://doi.org/10.1038/nsmb.2077.

[26] C. Lemaître, A. Grabarz, K. Tsouroula, L. Andronov, A. Furst, T. Pankotai, et al., Nuclear position dictates DNA repair pathway choice, Genes Dev. 28 (2014) 2450-2463, https://doi.org/10.1101/gad.248369.114.

[27] T. Clouaire, G. Legube, DNA double strand break repair pathway choice: a chromatin based decision? Nucleus 6 (2015) 107-113, https://doi.org/10.1080/19491034.2015. 1010946.
[28] A. Batté, C. Brocas, H. Bordelet, A. Hocher, M. Ruault, A. Adjiri, et al., Recombination at subtelomeres is regulated by physical distance, double-strand break resection and chromatin status, EMBO J. 36 (2017) 2609-2625, https:// doi.org/10.15252/embj.201796631.

[29] N. Agmon, B. Liefshitz, C. Zimmer, E. Fabre, M. Kupiec, Effect of nuclear architecture on the efficiency of doublestrand break repair, Nat. Cell Biol. 15 (2013) 694-699, https://doi.org/10.1038/ncb2745.

[30] C.-S. Lee, R.W. Wang, H.-H. Chang, D. Capurso, M.R. Segal, J.E. Haber, Chromosome position determines the success of double-strand break repair, Proc. Natl. Acad. Sci. U. S. A. 113 (2016) E146-E154, https://doi.org/10. 1073/pnas.1523660113.

[31] A. Marnef, G. Legube, Organizing DNA repair in the nucleus: DSBs hit the road, Curr. Opin. Cell Biol. 46 (2017) 1-8, https://doi.org/10.1016/j.ceb.2016.12.003.

[32] F. Aymard, G. Legube, A TAD closer to ATM, Molecular \& Cellular Oncology 3 (2016), e1134411. https://doi.org/10. 1080/23723556.2015.1134411.

[33] J.S. Iacovoni, P. Caron, I. Lassadi, E. Nicolas, L. Massip, D. Trouche, et al., High-resolution profiling of gammaH2AX around DNA double strand breaks in the mammalian genome, EMBO J. 29 (2010) 1446-1457, https://doi.org/ 10.1038/emboj.2010.38.

[34] P. Caron, F. Aymard, J.S. lacovoni, S. Briois, Y. Canitrot, B. Bugler, et al., Cohesin protects genes against $y \mathrm{H} 2 \mathrm{AX}$ Induced by DNA double-strand breaks, PLoS Genet. 8 (2012), e1002460. https://doi.org/10.1371/journal.pgen. 1002460.

[35] E. Lieberman-Aiden, N.L. van Berkum, L. Williams, M. Imakaev, T. Ragoczy, A. Telling, et al., Comprehensive mapping of long-range interactions reveals folding principles of the human genome, Science 326 (2009) 289-293, https://doi.org/10.1126/science.1181369.

[36] F. Natale, A. Rapp, W. Yu, A. Maiser, H. Harz, A. Scholl, et al., Identification of the elementary structural units of the DNA damage response, Nat. Commun. 8 (2017) 15760, https://doi.org/10.1038/ncomms15760.

[37] C.-S. Lee, K. Lee, G. Legube, J.E. Haber, Dynamics of yeast histone $\mathrm{H} 2 \mathrm{~A}$ and $\mathrm{H} 2 \mathrm{~B}$ phosphorylation in response to a double-strand break, Nat. Struct. Mol. Biol. 21 (2014) 103-109, https://doi.org/10.1038/nsmb.2737.

[38] H. Muller, V.F. Scolari, N. Agier, A. Piazza, A. Thierry, G. Mercy, et al., Characterizing meiotic chromosomes' structure and pairing using a designer sequence optimized for $\mathrm{Hi}-$ C, Mol. Syst. Biol. 14 (2018), e8293. https://doi.org/10. 15252/msb.20188293.

[39] J. Dekker, K. Rippe, M. Dekker, N. Kleckner, Capturing chromosome conformation, Science 295 (2002) 1306-1311, https://doi.org/10.1126/science.1067799.

[40] L. Patel, R. Kang, S.C. Rosenberg, Y. Qiu, R. Raviram, S. Chee, et al., Dynamic reorganization of the genome shapes the recombination landscape in meiotic prophase, Nat. Struct. Mol. Biol. 26 (2019) 164-174, https://doi.org/10. 1038/s41594-019-0187-0.

[41] S.A. Schalbetter, G. Fudenberg, J. Baxter, K.S. Pollard, M. J. Neale, Principles of meiotic chromosome assembly, BioRxiv (2018)https://doi.org/10.1101/442038.

[42] Y. Wang, H. Wang, Y. Zhang, Z. Du, W. Si, S. Fan, et al., Reprogramming of meiotic chromatin architecture during spermatogenesis, Mol. Cell 73 (2019) 547-561.e6, https:// doi.org/10.1016/j.molcel.2018.11.019. 
[43] K.G. Alavattam, S. Maezawa, A. Sakashita, H. Khoury, A. Barski, N. Kaplan, et al., Attenuated chromatin compartmentalization in meiosis and its maturation in sperm development, Nat. Struct. Mol. Biol. 26 (2019) 175-184, https://doi.org/10.1038/s41594-019-0189-y.

[44] J.P. Lao, N. Hunter, Trying to avoid your sister, PLoS Biol. 8 (2010), e1000519. https://doi.org/10.1371/journal.pbio. 1000519.

[45] V. Borde, B. de Massy, Meiosis: early DNA double-strand breaks pave the way for inter-homolog repair, Dev. Cell 32 (2015) 663-664, https://doi.org/10.1016/j.devcel.2015.03.011.

[46] Y. Blat, R.U. Protacio, N. Hunter, N. Kleckner, Physical and functional interactions among basic chromosome organizational features govern early steps of meiotic chiasma formation, Cell 111 (2002) 791-802, https://doi.org/10. 1016/S0092-8674(02)01167-4.

[47] K.P. Kim, B.M. Weiner, L. Zhang, A. Jordan, J. Dekker, N. Kleckner, Sister cohesion and structural axis components mediate homolog bias of meiotic recombination, Cell 143 (2010) 924-937, https://doi.org/10.1016/j.cell.2010.11.015.

[48] V. Sommermeyer, C. Béneut, E. Chaplais, M.E. Serrentino, V. Borde, Spp1, a member of the Set1 complex, promotes meiotic DSB formation in promoters by tethering histone H3K4 methylation sites to chromosome axes, Mol. Cell 49 (2013) 43-54, https://doi.org/10.1016/j.molcel.2012.11.008.

[49] S. Panizza, M.A. Mendoza, M. Berlinger, L. Huang, A. Nicolas, K. Shirahige, et al., Spo11-accessory proteins link double-strand break sites to the chromosome axis in early meiotic recombination, Cell 146 (2011) 372-383, https://doi. org/10.1016/j.cell.2011.07.003.

[50] L. Vian, A. Pękowska, S.S.P. Rao, K.-R. Kieffer-Kwon, S. Jung, L. Baranello, et al., The energetics and physiological impact of cohesin extrusion, Cell 173 (2018) 1165-1178. e20, https://doi.org/10.1016/j.cell.2018.03.072.

[51] P.P. Rocha, R. Raviram, Y. Fu, J. Kim, V.M. Luo, A. Aljoufi, et al., A damage-independent role for 53BP1 that impacts break order and Igh architecture during class switch recombination, Cell Rep. 16 (2016) 48-55, https://doi.org/ 10.1016/j.celrep.2016.05.073.

[52] E.L. Aiden, R. Casellas, Somatic rearrangement in B cells: it's (mostly) nuclear physics, Cell 162 (2015) 708-711, https://doi.org/10.1016/j.cell.2015.07.034.

[53] C. Guo, H.S. Yoon, A. Franklin, S. Jain, A. Ebert, H.-L. Cheng, et al., CTCF-binding elements mediate control of $\mathrm{V}$ (D)J recombination, Nature 477 (2011) 424-430, https://doi. org/10.1038/nature10495.

[54] S. Jain, Z. Ba, Y. Zhang, H.-Q. Dai, F.W. Alt, CTCF-binding elements mediate accessibility of RAG substrates during chromatin scanning, Cell 174 (2018) 102-116.e14, https:// doi.org/10.1016/j.cell.2018.04.035.

[55] E.M. Barajas-Mora, E. Kleiman, J. Xu, N.C. Carrico, H. Lu, E.M. Oltz, et al., A B-cell-specific enhancer orchestrates nuclear architecture to generate a diverse antigen receptor repertoire, Mol. Cell 73 (2019) 48-60.e5, https://doi.org/10. 1016/j.molcel.2018.10.013.

[56] S. Herbert, A. Brion, J.-M. Arbona, M. Lelek, A. Veillet, B. Lelandais, et al., Chromatin stiffening underlies enhanced locus mobility after DNA damage in budding yeast, EMBO J. 36 (2017) 2595-2608, https://doi.org/10.15252/embj. 201695842.

[57] C. Zimmer, E. Fabre, Chromatin mobility upon DNA damage: state of the art and remaining questions, Curr. Genet. 65 (2019) 1-9, https://doi.org/10.1007/s00294018-0852-6.
[58] M.S. Luijsterburg, I. de Krijger, W.W. Wiegant, R.G. Shah, G. Smeenk, A.J.L. de Groot, et al., PARP1 links CHD2mediated chromatin expansion and H3.3 deposition to DNA repair by non-homologous end-joining, Mol. Cell 61 (2016) 547-562, https://doi.org/10.1016/j.molcel.2016.01.019.

[59] H. Sellou, T. Lebeaupin, C. Chapuis, R. Smith, A. Hegele, H.R. Singh, et al., The poly(ADP-ribose)-dependent chromatin remodeler Alc1 induces local chromatin relaxation upon DNA damage, Mol. Biol. Cell 27 (2016) 3791-3799, https://doi.org/10.1091/mbc.E16-05-0269.

[60] R.C. Burgess, B. Burman, M.J. Kruhlak, T. Misteli, Activation of DNA damage response signaling by condensed chromatin, Cell Rep. 9 (2014) 1703-1717, https:// doi.org/10.1016/j.celrep.2014.10.060.

[61] M.J. Kruhlak, A. Celeste, G. Dellaire, O. FernandezCapetillo, W.G. Müller, J.G. McNally, et al., Changes in chromatin structure and mobility in living cells at sites of DNA double-strand breaks, J. Cell Biol. 172 (2006) 823-834, https://doi.org/10.1083/jcb.200510015.

[62] G. Dellaire, R. Kepkay, D.P. Bazett-Jones, High resolution imaging of changes in the structure and spatial organization of chromatin, gamma-H2A.X and the MRN complex within etoposide-induced DNA repair foci, Cell Cycle 8 (2009) 3750-3769, https://doi.org/10.4161/cc.8.22.10065.

[63] P. Oza, S.L. Jaspersen, A. Miele, J. Dekker, C.L. Peterson, Mechanisms that regulate localization of a DNA doublestrand break to the nuclear periphery, Genes Dev. 23 (2009) 912-927, https://doi.org/10.1101/gad.1782209.

[64] S. Nagai, K. Dubrana, M. Tsai-Pflugfelder, M.B. Davidson, T.M. Roberts, G.W. Brown, et al., Functional targeting of DNA damage to a nuclear pore-associated SUMOdependent ubiquitin ligase, Science 322 (2008) 597-602, https://doi.org/10.1126/science.1162790.

[65] F. Aymard, M. Aguirrebengoa, E. Guillou, B.M. Javierre, B. Bugler, C. Arnould, et al., Genome-wide mapping of longrange contacts unveils clustering of DNA double-strand breaks at damaged active genes, Nat. Struct. Mol. Biol. 24 (2017) 353-361, https://doi.org/10.1038/nsmb.3387.

[66] T. Clouaire, A. Marnef, G. Legube, Taming tricky DSBs: ATM on duty, DNA Repair (Amst) 56 (2017) 84-91, https:// doi.org/10.1016/j.dnarep.2017.06.010.

[67] M.J. Smith, R. Rothstein, Poetry in motion: increased chromosomal mobility after DNA damage, DNA Repair (Amst) 56 (2017) 102-108, https://doi.org/10.1016/j.dnarep. 2017.06.012.

[68] V. Garcia, S. Gray, R.M. Allison, T.J. Cooper, M.J. Neale, Tel1(ATM)-mediated interference suppresses clustered meiotic double-strand-break formation, Nature 520 (2015) 114-118, https://doi.org/10.1038/nature13993.

[69] T.J. Cooper, V. Garcia, M.J. Neale, Meiotic DSB patterning: a multifaceted process, Cell Cycle 15 (2016) 13-21, https:// doi.org/10.1080/15384101.2015.1093709.

[70] P.R. Potts, M.H. Porteus, H. Yu, Human SMC5/6 complex promotes sister chromatid homologous recombination by recruiting the $\mathrm{SMC} 1 / 3$ cohesin complex to double-strand breaks, EMBO J. 25 (2006) 3377-3388, https://doi.org/10. 1038/sj.emboj.7601218.

[71] E. Unal, A. Arbel-Eden, U. Sattler, R. Shroff, M. Lichten, J.E. Haber, et al., DNA damage response pathway uses histone modification to assemble a double-strand break-specific cohesin domain, Mol. Cell 16 (2004) 991-1002, https://doi. org/10.1016/j.molcel.2004.11.027.

[72] L. Ström, H.B. Lindroos, K. Shirahige, C. Sjögren, Postreplicative recruitment of cohesin to double-strand breaks is 
required for DNA repair, Mol. Cell 16 (2004) 1003-1015, https://doi.org/10.1016/j.molcel.2004.11.026.

[73] C. Bot, A. Pfeiffer, F. Giordano, D.E. Manjeera, N.P. Dantuma, L. Ström, Independent mechanisms recruit the cohesin loader protein NIPBL to sites of DNA damage, J. Cell Sci. 130 (2017) 1134-1146, https://doi.org/10.1242/jcs. 197236.

[74] Meisenberg C, Pinder SI, Hopkins SR, Wooller SK, Benstead-Hume G, Pearl FMG, et al. Repression of transcription at DNA breaks requires cohesin throughout interphase and prevents genome instability. Mol Cell 2019; 73:212-223.e7. doi:10.1016/j.molcel.2018.11.001.

[75] L. Ström, C. Karlsson, H.B. Lindroos, S. Wedahl, Y. Katou, K. Shirahige, et al., Postreplicative formation of cohesion is required for repair and induced by a single DNA break, Science 317 (2007) 242-245, https://doi.org/10.1126/ science.1140649.

[76] S.-T. Kim, B. Xu, M.B. Kastan, Involvement of the cohesin protein, Smc1, in Atm-dependent and independent responses to DNA damage, Genes Dev. 16 (2002) 560-570, https://doi.org/10.1101/gad.970602.

[77] N. Wu, X. Kong, Z. Ji, W. Zeng, P.R. Potts, K. Yokomori, et al., Scc1 sumoylation by Mms21 promotes sister chromatid recombination through counteracting Wapl, Genes Dev. 26 (2012) 1473-1485, https://doi.org/10.1101/ gad.193615.112.

[78] Hellmuth S, Gutiérrez-Caballero C, Llano E, Pendás AM, Stemmann O. Local activation of mammalian separase in interphase promotes double-strand break repair and prevents oncogenic transformation. EMBO J 2018;37. doi: 10.15252/embj.201899184.

[79] Y. Oka, K. Suzuki, M. Yamauchi, N. Mitsutake, S. Yamashita, Recruitment of the cohesin loading factor NIPBL to DNA double-strand breaks depends on MDC1, RNF168 and HP1y in human cells, Biochem. Biophys. Res. Commun. 411 (2011) 762-767, https://doi.org/10.1016/j. bbrc.2011.07.021.

[80] J. Lightfoot, S. Testori, C. Barroso, E. Martinez-Perez, Loading of meiotic cohesin by SCC-2 is required for early processing of DSBs and for the DNA damage checkpoint, Curr. Biol. 21 (2011) 1421-1430, https://doi.org/10.1016/j. cub.2011.07.007.

[81] X. Kong, A.R. Ball, H.X. Pham, W. Zeng, H.-Y. Chen, J.A. Schmiesing, et al., Distinct functions of human cohesin-SA1 and cohesin-SA2 in double-strand break repair, Mol. Cell. Biol. 34 (2014) 685-698, https://doi.org/10.1128/MCB. 01503-13.

[82] P.T. Yazdi, Y. Wang, S. Zhao, N. Patel, E.Y.-H.P. Lee, J. Qin, SMC1 is a downstream effector in the ATM/NBS1 branch of the human S-phase checkpoint, Genes Dev. 16 (2002) 571-582, https://doi.org/10.1101/gad.970702.

[83] E. Unal, J.M. Heidinger-Pauli, D. Koshland, DNA doublestrand breaks trigger genome-wide sister-chromatid cohesion through Eco1 (Ctf7), Science 317 (2007) 245-248, https://doi.org/10.1126/science.1140637.

[84] A. McAleenan, V. Cordon-Preciado, A. Clemente-Blanco, I.C. Liu, N. Sen, J. Leonard, et al., SUMOylation of the $\alpha-$ kleisin subunit of cohesin is required for DNA damageinduced cohesion, Curr. Biol. 22 (2012) 1564-1575, https:// doi.org/10.1016/j.cub.2012.06.045.

[85] J.M. Heidinger-Pauli, E. Unal, D. Koshland, Distinct targets of the Eco1 acetyltransferase modulate cohesion in S phase and in response to DNA damage, Mol. Cell 34 (2009) 311-321, https://doi.org/10.1016/j.molcel.2009.04.008.
[86] N. Takahashi, M. Quimbaya, V. Schubert, T. Lammens, K. Vandepoele, I. Schubert, et al., The MCM-binding protein ETG1 aids sister chromatid cohesion required for postreplicative homologous recombination repair, PLoS Genet. 6 (2010), e1000817. https://doi.org/10.1371/journal.pgen. 1000817.

[87] C. Bauerschmidt, C. Arrichiello, S. Burdak-Rothkamm, M. Woodcock, M.A. Hill, D.L. Stevens, et al., Cohesin promotes the repair of ionizing radiation-induced DNA double-strand breaks in replicated chromatin, Nucleic Acids Res. 38 (2010) 477-487, https://doi.org/10.1093/nar/gkp976.

[88] S. Covo, J.W. Westmoreland, D.A. Gordenin, M.A. Resnick, Cohesin is limiting for the suppression of DNA damageinduced recombination between homologous chromosomes, PLoS Genet. 6 (2010), e1001006. https://doi.org/ 10.1371/journal.pgen.1001006.

[89] C. Sjögren, K. Nasmyth, Sister chromatid cohesion is required for postreplicative double-strand break repair in Saccharomyces cerevisiae, Curr. Biol. 11 (2001) 991-995, https://doi.org/10.1016/S0960-9822(01)00271-8.

[90] H. Dodson, C.G. Morrison, Increased sister chromatid cohesion and DNA damage response factor localization at an enzyme-induced DNA double-strand break in vertebrate cells, Nucleic Acids Res. 37 (2009) 6054-6063, https://doi. org/10.1093/nar/gkp684.

[91] C. Gelot, J. Guirouilh-Barbat, B.S. Lopez, The cohesin complex prevents the end-joining of distant DNA doublestrand ends in $S$ phase: consequences on genome stability maintenance, Nucleus 7 (2016) 339-345, https://doi.org/10. 1080/19491034.2016.1194159.

[92] F. Lang, X. Li, W. Zheng, Z. Li, D. Lu, G. Chen, et al., CTCF prevents genomic instability by promoting homologous recombination-directed DNA double-strand break repair, Proc. Natl. Acad. Sci. U. S. A. 114 (2017) 10912-10917, https://doi.org/10.1073/pnas.1704076114.

[93] K. Hilmi, M. Jangal, M. Marques, T. Zhao, A. Saad, C. Zhang, et al., CTCF facilitates DNA double-strand break repair by enhancing homologous recombination repair, Sci. Adv. 3 (2017), e1601898. https://doi.org/10.1126/sciadv. 1601898.

[94] D. Han, Q. Chen, J. Shi, F. Zhang, X. Yu, CTCF participates in DNA damage response via poly(ADP-ribosyl)ation, Sci. Rep. 7 (2017) 43530, https://doi.org/10.1038/srep43530.

[95] Clouaire T, Rocher V, Lashgari A, Arnould C, Aguirrebengoa $M$, Biernacka $A$, et al. Comprehensive mapping of histone modifications at DNA double-strand breaks deciphers repair pathway chromatin signatures. Mol Cell 2018; 72:250-262.e6. doi:10.1016/j.molcel.2018.08.020.

[96] S. Feldman, R. Wuerffel, I. Achour, L. Wang, P.B. Carpenter, A.L. Kenter, 53BP1 contributes to Igh locus chromatin topology during class switch recombination, J. Immunol. 198 (2017) 2434-2444, https://doi.org/10.4049/ jimmunol.1601947.

[97] J.R. Chapman, P. Barral, J.-B. Vannier, V. Borel, M. Steger, A. Tomas-Loba, et al., RIF1 is essential for 53BP1dependent nonhomologous end joining and suppression of DNA double-strand break resection, Mol. Cell 49 (2013) 858-871, https://doi.org/10.1016/j.molcel.2013.01.002.

[98] M. Di Virgilio, E. Callen, A. Yamane, W. Zhang, M. Jankovic, A.D. Gitlin, et al., Rif1 prevents resection of DNA breaks and promotes immunoglobulin class switching, Science 339 (2013) 711-715, https://doi.org/10.1126/science.1230624.

[99] M. Zimmermann, F. Lottersberger, S.B. Buonomo, A. Sfeir, T. de Lange, 53BP1 regulates DSB repair using Rif1 to 
control $5^{\prime}$ end resection, Science 339 (2013) 700-704, https://doi.org/10.1126/science.1231573.

[100] R. Foti, S. Gnan, D. Cornacchia, V. Dileep, A. Bulut-Karslioglu, S. Diehl, et al., Nuclear architecture organized by Rif1 underpins the replication-timing program, Mol. Cell 61 (2016) 260-273, https://doi.org/10.1016/j.molcel.2015.12.001.

[101] J.P. Manis, J.C. Morales, Z. Xia, J.L. Kutok, F.W. Alt, P.B. Carpenter, 53BP1 links DNA damage-response pathways to immunoglobulin heavy chain class-switch recombination, Nat. Immunol. 5 (2004) 481-487, https://doi.org/10.1038/ni1067.

[102] A. Bothmer, D.F. Robbiani, M. Di Virgilio, S.F. Bunting, I.A. Klein, N. Feldhahn, et al., Regulation of DNA end joining, resection, and immunoglobulin class switch recombination by 53BP1, Mol. Cell 42 (2011) 319-329, https://doi.org/10. 1016/j.molcel.2011.03.019.

[103] T. Ryu, B. Spatola, L. Delabaere, K. Bowlin, H. Hopp, R. Kunitake, et al., Heterochromatic breaks move to the nuclear periphery to continue recombinational repair, Nat. Cell Biol. 17 (2015) 1401-1411, https://doi.org/10.1038/ncb3258.

[104] C. Horigome, E. Unozawa, T. Ooki, T. Kobayashi, Ribosomal RNA gene repeats associate with the nuclear pore complex for maintenance after DNA damage, PLoS Genet. 15 (2019), e1008103. https://doi.org/10.1371/journal.pgen.1008103.

[105] K. Tsouroula, A. Furst, M. Rogier, V. Heyer, A. MaglottRoth, A. Ferrand, et al., Temporal and spatial uncoupling of DNA double strand break repair pathways within mammalian heterochromatin, Mol. Cell 63 (2016) 293-305, https:// doi.org/10.1016/j.molcel.2016.06.002.

[106] M. van Sluis, B. McStay, A localized nucleolar DNA damage response facilitates recruitment of the homology-directed repair machinery independent of cell cycle stage, Genes Dev. 29 (2015) 1151-1163, https://doi.org/10.1101/gad.260703.115.

[107] S.M. Harding, J.A. Boiarsky, R.A. Greenberg, ATM dependent silencing links nucleolar chromatin reorganization to DNA damage recognition, Cell Rep. 13 (2015) 251-259, https://doi.org/10.1016/j.celrep.2015.08.085.

[108] J.A. Aten, J. Stap, P.M. Krawczyk, C.H. van Oven, R.A. Hoebe, J. Essers, et al., Dynamics of DNA double-strand breaks revealed by clustering of damaged chromosome domains, Science 303 (2004) 92-95, https://doi.org/10. 1126/science.1088845.

[109] P.M. Krawczyk, J. Stap, C. van Oven, R. Hoebe, J.A. Aten, Clustering of double strand break-containing chromosome domains is not inhibited by inactivation of major repair proteins, Radiat. Prot. Dosim. 122 (2006) 150-153, https:// doi.org/10.1093/rpd/ncl479.

[110] T. Neumaier, J. Swenson, C. Pham, A. Polyzos, A.T. Lo, P. Yang, et al., Evidence for formation of DNA repair centers and dose-response nonlinearity in human cells, Proc. Natl. Acad. Sci. U. S. A. 109 (2012) 443-448, https://doi.org/10. 1073/pnas.1117849108.

[111] N.W. Cho, R.L. Dilley, M.A. Lampson, R.A. Greenberg, Interchromosomal homology searches drive directional ALT telomere movement and synapsis, Cell 159 (2014) 108-121, https://doi.org/10.1016/j.cell.2014.08.030.

[112] P. Caron, J. Choudjaye, T. Clouaire, B. Bugler, V. Daburon, M. Aguirrebengoa, et al., Non-redundant functions of ATM and DNA-PKcs in response to dna double-strand breaks, Cell Rep. 13 (2015) 1598-1609, https://doi.org/10.1016/j. celrep.2015.10.024.

[113] P.M. Krawczyk, T. Borovski, J. Stap, T. Cijsouw, R. ten Cate, J.P. Medema, et al., Chromatin mobility is increased at sites of DNA double-strand breaks, J. Cell Sci. 125 (2012) 2127-2133, https://doi.org/10.1242/jcs.089847.
[114] B.R. Schrank, T. Aparicio, Y. Li, W. Chang, B.T. Chait, G.G. Gundersen, et al., Nuclear ARP2/3 drives DNA break clustering for homology-directed repair, Nature 559 (2018) 61-66, https://doi.org/10.1038/s41586-018-0237-5.

[115] D.P. Waterman, F. Zhou, K. Li, C.-S. Lee, M. Tsabar, V.V. Eapen, et al., Live cell monitoring of double strand breaks in S. cerevisiae, PLoS Genet 15 (2019), e1008001. https://doi. org/10.1371/journal.pgen.1008001.

[116] A. Guénolé, G. Legube, A meeting at risk: unrepaired DSBs go for broke, Nucleus 8 (2017) 589-599, https://doi.org/10. 1080/19491034.2017.1380138.

[117] V. Hurst, K. Shimada, S.M. Gasser, Nuclear actin and actinbinding proteins in DNA repair, Trends Cell Biol. 29 (2019) 462-476, https://doi.org/10.1016/j.tcb.2019.02.010.

[118] V.N. Evdokimova, M. Gandhi, A.V. Nikitski, C.J. Bakkenist, Y.E. Nikiforov, Nuclear myosin/actin-motored contact between homologous chromosomes is initiated by ATM kinase and homology-directed repair proteins at doublestrand DNA breaks to suppress chromosome rearrangements, Oncotarget 9 (2018) 13612-13622, https://doi.org/ 10.18632/oncotarget.24434.

[119] C.P. Caridi, C. D’Agostino, T. Ryu, G. Zapotoczny, L. Delabaere, X. Li, et al., Nuclear F-actin and myosins drive relocalization of heterochromatic breaks, Nature 559 (2018) 54-60, https://doi.org/10.1038/s41586-018-0242-8.

[120] B.J. Belin, T. Lee, R.D. Mullins, DNA damage induces nuclear actin filament assembly by Formin-2 and Spire- $-1 / 2$ that promotes efficient DNA repair [corrected], Elife 4 (2015), e07735. https://doi.org/10.7554/eLife.07735.

[121] F. Lottersberger, R.A. Karssemeijer, N. Dimitrova, T. de Lange, 53BP1 and the LINC complex promote microtubuledependent DSB mobility and DNA repair, Cell 163 (2015) 880-893, https://doi.org/10.1016/j.cell.2015.09.057.

[122] J. Lawrimore, T.M. Barry, R.M. Barry, A.C. York, B. Friedman, D.M. Cook, et al., Microtubule dynamics drive enhanced chromatin motion and mobilize telomeres in response to DNA damage, Mol. Biol. Cell 28 (2017) 1701-1711, https://doi.org/10.1091/mbc.E16-12-0846.

[123] A. Amitai, A. Seeber, S.M. Gasser, D. Holcman, Visualization of chromatin decompaction and break site extrusion as predicted by statistical polymer modeling of single-locus trajectories, Cell Rep. 18 (2017) 1200-1214, https://doi.org/ 10.1016/j.celrep.2017.01.018.

[124] R. Oshidari, J. Strecker, D.K.C. Chung, K.J. Abraham, J.N. Y. Chan, C.J. Damaren, et al., Nuclear microtubule filaments mediate non-linear directional motion of chromatin and promote DNA repair, Nat. Commun. 9 (2018) 2567, https://doi.org/10.1038/s41467-018-05009-7.

[125] A.G. Larson, D. Elnatan, M.M. Keenen, M.J. Trnka, J.B. Johnston, A.L. Burlingame, et al., Liquid droplet formation by HP1a suggests a role for phase separation in heterochromatin, Nature 547 (2017) 236-240, https://doi.org/10. 1038/nature22822.

[126] A.R. Strom, A.V. Emelyanov, M. Mir, D.V. Fyodorov, X. Darzacq, G.H. Karpen, Phase separation drives heterochromatin domain formation, Nature 547 (2017) 241-245, https://doi.org/10.1038/nature22989.

[127] C. Baldeyron, G. Soria, D. Roche, A.J.L. Cook, G. Almouzni, HP1alpha recruitment to DNA damage by p150CAF-1 promotes homologous recombination repair, J. Cell Biol. 193 (2011) 81-95, https://doi.org/10.1083/jcb. 201101030

[128] Y.-H. Lee, C.-Y. Kuo, J.M. Stark, H.-M. Shih, D.K. Ann, HP1 promotes tumor suppressor BRCA1 functions during the 
DNA damage response, Nucleic Acids Res. 41 (2013) 5784-5798, https://doi.org/10.1093/nar/gkt231.

[129] W. Wu, H. Nishikawa, T. Fukuda, V. Vittal, M. Asano, Y. Miyoshi, et al., Interaction of BARD1 and HP1 is required for BRCA1 retention at sites of DNA damage, Cancer Res. 75 (2015) 1311-1321, https://doi.org/10.1158/0008-5472. CAN-14-2796.

[130] M. Alagoz, Y. Katsuki, H. Ogiwara, T. Ogi, A. Shibata, A. Kakarougkas, et al., SETDB1, HP1 and SUV39 promote repositioning of 53BP1 to extend resection during homologous recombination in G2 cells, Nucleic Acids Res. 43 (2015) 7931-7944, https://doi.org/10.1093/nar/gkv722.

[131] M.S. Luijsterburg, C. Dinant, H. Lans, J. Stap, E. Wiernasz, S. Lagerwerf, et al., Heterochromatin protein 1 is recruited to various types of DNA damage, J. Cell Biol. 185 (2009) 577-586, https://doi.org/10.1083/jcb.200810035.

[132] M.K. Ayrapetov, O. Gursoy-Yuzugullu, C. Xu, Y. Xu, B.D. Price, DNA double-strand breaks promote methylation of histone $\mathrm{H} 3$ on lysine 9 and transient formation of repressive chromatin, Proc. Natl. Acad. Sci. U. S. A. 111 (2014) 9169-9174, https://doi.org/10.1073/pnas.1403565111.

[133] M. Altmeyer, K.J. Neelsen, F. Teloni, I. Pozdnyakova, S. Pellegrino, M. Grøfte, et al., Liquid demixing of intrinsically disordered proteins is seeded by poly(ADP-ribose), Nat. Commun. 6 (2015) 8088, https://doi.org/10.1038/ ncomms 9088 .

[134] Singatulina AS, Hamon L, Sukhanova MV, Desforges B, Joshi V, Bouhss A, et al. PARP-1 activation directs FUS to DNA damage sites to form PARG-reversible compartments enriched in damaged DNA. Cell Rep 2019;27:1809-1821. e5. doi:10.1016/j.celrep.2019.04.031.

[135] Kilic S, Lezaja A, Gatti M, Bianco E, Michelena J, Imhof R, et al. Phase separation of 53BP1 determines liquid-like behavior of DNA repair compartments. EMBO J 2019: e101379. doi:10.15252/embj.2018101379.

[136] Y. Zhang, R.P. McCord, Y.-J. Ho, B.R. Lajoie, D.G. Hildebrand, A.C. Simon, et al., Spatial organization of the mouse genome and its role in recurrent chromosomal translocations, Cell 148 (2012) 908-921, https://doi.org/10. 1016/j.cell.2012.02.002.

[137] H.J. Gothe, V. Minneker, V. Roukos, Dynamics of doublestrand breaks: implications for the formation of chromosome translocations, Adv. Exp. Med. Biol. 1044 (2018) 27-38, https://doi.org/10.1007/978-981-13-0593-1_3. 